\title{
Georges Bataille, François Perroux and French Critiques of the Marshall Plan
}

\author{
Raphaël Fèvre
}

University of Cambridge|rf438@cam.ac.uk

\begin{abstract}
This paper assesses French intellectuals' early reception of the Marshall Plan in the light of the discussion Georges Bataille (1897-1962) and François Perroux (1903-1987) had in the journal Critique, by the second-half of 1948. I argue that Bataille and Perroux parallel efforts to go beyond what they perceive as the narrow boundaries of economics is mainly responsible for their unexpectedly optimistic reception of the American aid. The paper shows that the Perroux-Bataille discussion involved additional participants (as Jean Piel, and through him foreign economists like Colin Clark and Alvin Hansen). Those will help us grasping in more depth Bataille's original account of the Marshall Plan, as well as assessing his disagreement with Perroux.
\end{abstract}

Keywords: Georges Bataille, General Economy, Marshall Plan, François Perroux, Gift

Fèvre, Raphaël. 2019. "Georges Bataille, François Perroux and French Critiques of the Marshall Plan.” OSF Preprints. July 6. doi:10.31219/osf.io/acb6z. 


\section{Georges Bataille, François Perroux and French Critiques of the Marshall Plan}

The moment would arrive when passion would no longer be an agent of unawareness. It will be said that only a madman could perceive such things in the Marshall and Truman plans. I am that madman.

Georges Bataille, La Part Maudite (1949)

After twenty years, I know he [Bataille] was right, as I immediately felt. Today, however, I understand; on the occasion of the same events... we were, one and the other, elsewhere. Not in the same kingdom.

François Perroux, La Part Maudite et le silence (1971)

This article is concerned with French intellectuals' early reception of the Marshall Plan, while the European Recovery Program was still highly hypothetical, and its modus operandi barely outlined. 1 The paper is thus less interested in technical considerations of the Plan, than in the way intellectuals reacted to the hopes and fears fuelled by this upcoming American aid. I will do so by shedding light on the exchange Georges Bataille (1897-1962) and the economist François Perroux (1903-1987) had following the publication, by the latter, of Le Plan Marshall ou L'Europe nécessaire au Monde (Perroux 1948b).

\footnotetext{
${ }^{1}$ George Marshall's Harvard speech of June $5^{\text {th }}, 1947$, paved the way to a massive American aid to support European economies' recovery from the war. From mid 1948 until the end of 1951, the Plan supplied Europe with US\$ 13 billon. Nearly 90 per cent of the total amount consisted in straight gifts. Often depicted as "History's most successful structural adjustment program" (De Long et Eichengreen 1993), the Marshall Plan was one of the cornerstone in US ambition to design a framework for postwar multilateral trade. Due to its scope and political implications, the European Recovery Program marked a decisive step toward the rise of the Cold War (see Steil 2018).
} 
This discussion took shape by the second half of 1948 in Critique, Bataille's newly founded journal. Perroux also invited him to give a lecture at the Institute of Applied Economic Science (ISEA) on June $8^{\text {th }}, 1949$, following the recent publication of Bataille's masterpiece La Part Maudite (O.C.VII). ${ }^{2}$ From this exchange, it appears that Perroux and Bataille showed a fairly supportive and optimistic reception of the Marshall Plan. This is surprising for two reasons. First, because most French intellectuals were, when not outright opposed to the American Aid, at best very sceptical about it. Second, and more notably, because during the inter-war period, both authors had no words strong enough to express their contempt for the liberal values embodied by American capitalism. ${ }^{3}$ It is a puzzle then, how can we understand their unexpected positive appreciation of the American initiative?

My contention is that Perroux's and Bataille's diverse but original accounts of the Marshall Plan can be explained by their parallel efforts to go beyond what they perceived as the narrow boundaries of economics. In other words, their discussion, far from being trivial, marked a decisive step for both authors - playing however a different role in their respective intellectual journey. For Bataille, the Marshall Plan worked as a catalyst fulfilling an eighteen years effort to build up an economic interpretation "up to [à la mesure] the universe" (O.C.VII, 7). By contrast for Perroux, the American aid provided an opportunity to foreground some innovative analytical insigths, apparently disconnected from his interwar

\footnotetext{
${ }^{2}$ Regarding Bataille, the article draw as far as possible on his Euvres complètes (O.C.). For an english version of The Accursed Share, see Bataille (Bataille 1991). In addition, the paper makes some references to Perroux's papers [PRX], that are hold since 2004 by the French Institute for Contemporary Publishing Archives of Caen. Translations of French authors are mine.

${ }^{3}$ Bataille drew his criticism from a — non-orthodox — communist standpoint (see Pawlett 2015), while Perroux endorsed a communautarian and personalist ideal (see Brisset et Fèvre 2018).
} 
corporatist leanings (untenable on the post-war political scene). They both, however, took the Marshall Plan as an enigma that current economics was not able to account for, stimulation their craving for new theoretical perspectives.

The Perroux-Bataille dialogue, neglected by the literature on Perroux, has long been merely noticed in the Bataille studies (Richman 1990, 155; Stoek1 1997, 245; Dandurand 1998, 6). Recently however, some contributors have taken opposite views on this exchange (De March 2015; Dodd 2016; McGoey 2017). On the one hand, François de March (2015) confined the discussion between the two authors to what he called an epistemological disagreement. Perroux's (alleged $\left.{ }^{4}\right)$ Popperian plea for scientific reasoning would epitomiseand accordingly explain — economists' general lack of interest for Bataille's contributions (De March 2015, 120-122) . On the other hand, Nigel Dodd $(2016,207)$ has pointed at Bataille's and Perroux's similar aims: the building of a general outlook on economic issues opposed to a microeconomic viewpoint based on marginalist economics (see also McGoey 2017, 6). Their fairly brief analysis of the Perroux-Bataille exchange was only a passing episode in studies of Bataille's thought.

In this paper, I shall elaborate on both the individual and general implications of the Bataille-Perroux debate by contextualising it within the French intellectual debates of the time. The discussion between Perroux and Bataille was not a tête-à-tête, but involveddirectly and indirectly — additional participants. A central but neglected piece in the puzzle was Jean Piel, Bataille's friend and key contributor to Critique. Piel was an administrative economist, not an academic one like Perroux. I will show that Piel acted as a mediator who introduced Bataille to foreign economics, in particular to American debates on economic

\footnotetext{
${ }^{4}$ Perroux developped in fact a much finer methodology than the implicist refutationism of the economic profession (see Dufourt 2009; Caldari 2018).
} 
maturity. Piel's analysis of the Marshall Plan consisted in a rather usual form of economic reasoning though tinted with Bataillian elements. This will help us assessing in more depth Bataille's analysis, as well as his disagreement with Perroux.

\section{French Politics, Intellectuals and the Marshall Plan}

The European Recovery Program was officially under way on April $3^{\text {nd }}$, 1948, with President Harry Truman ratifying the Foreign Assistance Act after lengthy discussions in Congress. Then only designed for a year, the Marshall Plan would continue beyond this period amid conclusive results in Europe, and encouraging domestic circumstances in the US. About US\$ 5 billion were granted to sixteens countries, yet half of the aid went exclusively to two countries: Great-Britain and France. ${ }^{5}$ None of the Eastern European popular democracies were to receive the American aid, because Moscow reject the Marshall initiative.

The Paris meeting of June-July 1947 between the "Three Powers"-Great-Britain, France and the Soviet Union—only confirmed the rising East/West tension. By October 1947, the Soviet Union set forth an international political organ - the Kominform - in charge of dictating the official communist doctrine for the satellite states (see Roberts 1994). In France, this sequence of events led to the internal split of the Left, isolating even more the Communist Party (PCF) from coalition parties (Dulphy 2005, 417). The hopes and fears fuelled by this international American "experiment” (Véran 1948, 547) monopolized French intellectual

\footnotetext{
${ }^{5}$ The American aid was welcomed by Austria, the Benelux, Denmark, Greece, Iceland, Italy, Ireland, Norway, Portugal, Sweden, Switzerland and Turkey (the aid wasn't offered to Franco's Spain). The "Sixteens" turned officially seventeens when West Germany, previously administered by the occupying powers, became a Federal Republic on May 1949.
} 
debates on political and economic matters, pushing scholars from various backgrounds to take a stand on the- - highly polarized—public stage.

Will France become an American Colony? - by this title alone, Georges Soria's book (1948) captured the mood that was in the air since the announcement of Truman and Marshall plans. France's ability to remain independent from the US, while accepting their aid, was indeed a much-debated issue. According to Soria, member of the PCF, the Marshall Plan was at the same time useless and dangerous for France. It was useless regarding the economic recovery, as France embarked on its own domestic indicative planning, known as the Monnet Plan (see Lynch 1984). The Marshall Plan was dangerous because the economic aid would only be the prelude to a political and military agreement against the Eastern Bloc.

In front of the systematic condemnation of the American aid by the communists, most intellectuals were desperate to see a wholehearted endorsement of it by governmental parties (Fraisse 1948, 626). If the upcoming of the Marshall Plan accomplished anything in the political stage, it was demonstrating French parties' "complete bankruptcy of their task of political education" (Goguel 1948, 621). Intellectual debates overlapped to a large extent with this polarized political mood, but not entirely. In the following, I will focus on contributions that went beyond a Manichean contrast between hidden imperialism on the one hand, and pure generosity on the other.

The notion of foreign aid — a non-reciprocal and unilateral transfer of wealth-was born from the aftermath of the two World Wars, and as such was a relatively new issue to address (Thérien 2002, 449) . Debates on the implication of the Marshall Plan were particularly lively among French intellectuals. General periodicals were the privileged medium for public discussions in the post-war period, following a trend that emerged in 
the inter-war years. The Catholic journal Esprit, founded in 1932 by Emmanuel Mounier, soon became the favorite means of intellectuals' public voice (Winock 1996). However, new titles became increasingly influential in the aftermath of the war: such was the case of Les Temps Modernes, founded by Jean-Paul Sartre and Simone de Beauvoir in 1945.

Publications in Esprit and Les Temps Modernes offered balanced views in contrast with the black-and-white political analyses provided by the government and the communist opposition (Drake 2002, 55). Both journals considered it key that the US would prove able to keep political and economic issues separate. The Marshall Plan could be a good opportunity for modernising the French economy, if it merged with the Monnet Plan that was still at an early stage (Rabier 1948). However, as Pierre Uri (1948, 33) emphasised, Americans endorsed a rather different strategy, conditioning the economic aid to voting outcomes: menacing for instance Italy to be "withdraw for the beneficiary list" if the forthcoming elections of the Parliament were to be "non-satisfactory."

Most contributors to Les Temps Modernes also insisted that if the Marshall Plan was not imperialist in nature, it had to be re-orientated toward working class interests. American's strategic interests regarding key-industry capital, in particular in Germany, where the prospects of profit were high, was tantamount to "economic colonisation" (Véran 1948, 549) . Jean Domarchi (professor of economics and regular contributor to Sartre's journal) was among the strongest critical voices of the American aid. Though translator of William Beveridge and close to Keynesian ideas, Domarchi opposed this model of a European New Deal. He saw the Marshall Plan as an international way to support American - highly monopolistic — industries at the expense of a domestic fullemployment policy (Domarchi 1948, 1349). 
Esprit and Les Temps Modernes were not the only journals to take a stand on the forthcoming American aid, and examples could be multiplied. But these two leading journals reflected and crystallized — however nuanced — the "mass anti-Americanism" widespread among the French population. ${ }^{6}$ At the beginning of 1948, about two thirds of the population were against the US aid (Scot 2016, 384). Still, this prevailing opinion was not shared by all intellectuals; and Critique, the journal founded by Bataille, proved a welcoming place for a more constructive — though exacting — perspective on the Marshall Plan.

\section{Critique's Economy}

Subtitled "General journal of French and foreign publications," Critique was first issued in June 1946. By distinctive book reviews and short notes, Critique aimed at dealing with the most recent contributions "in the fields of literary creation, of philosophical studies, of historical, scientific, political and economic knowledge" (in Patron 2000, 37). From the beginning, leading intellectuals such as Raymond Aron, or Bataille's friends Maurice Blanchot and Alexandre Kojève contributed to it. The latter introduced a whole generation of young intellectuals to his Hegel (Sabot 2014). Designated best French journal of the year 1948 by journalists, Critique soon stood out from competing titles by its academic tone, and by the absence of an official editorial line on political issues (Patron 2000, 59).

In Critique's early years, Bataille took every possible subject as the occasion to elaborate on the rising West/Est tensions and to support his own conception of political

\footnotetext{
${ }^{6}$ The American aid conveyed, together with political and economic aspects such as the importation of management (Boltanski 1981), social and cultural representations that are beyond the scope of this article (see Holm 2016; Kroen 2006).
} 
economy. An emblematic example of this approach is perhaps Bataille's 1947 survey of existentialist philosophy (in particular the work of Levinas), which he compared to his own economic point of view in the last pages (O.C.XI, 299-306). Bataille's most fascinating insight came from a review devoted to a study of the aftermaths of Hiroshima, issued in February 1947 (O.C.XI, 186-7). At that moment, Bataille somehow predicted the Marshall Plan, stressing that "the normal and necessary movement of the US activity should effortlessly result in the equipping of the whole globe without a corresponding counterpart" (O.C.XI, 186).

Bataille's “anticipation” (Surya 2002, 377) was rooted in writings on economic issues he restlessly reworked during the interwar period. His long 1933 article "La notion de dépense" was a crucial—while not the earliest—groundwork (O.C.I). Yet Bataille's post-war book reviews were neither mere digressions, nor further illustrations of an already established theoretical apparatus. On the contrary, those book reviews greatly contributed to shape and complete Bataille's eighteen years effort, published in 1949 under the title The Accursed Share (O.C.VII, 17, sqq.). In the interwar, Bataille elaborated most of the middle chapters ("The Historical Data") concerning the study of primitive societies. ${ }^{7}$ But the theoretical introduction and the fifth chapter ("The Present Data") were outlined in the light of the latest international events. This final chapter was almost exclusively made up of his book reviews, with the same texts rearranged. In short, the American aid was the last element to give Bataille's view concerning our modern industrial society its entire relevance and significance. In this process, the reading of Perroux played a central role. But before addressing the Perroux-Bataille exchange of 1948, a third protagonist should be introduced: Bataille's

\footnotetext{
${ }^{7}$ Bataille's debts to Durkeimian sociology, and in particular to Marcel Mauss' famous essay The Gift, is well researched (see Falasca-Zamponi 2011, chap. 1; Marcel 2003; Ramp 2003; Richman 2002).
} 
brother-in-law Jean Piel (they both married Maklès sisters). From the beginning Piel was deeply involved in the Critique project. A philosophy graduate, he had a sound grasp of economic issues in his quality of high placed civil servant (haut fonctionnaire) at the direction of the Économie générale, attached to the Ministry of Finance. From 1946 to 1948, Piel contributed four review articles to Critique, all on economic research. The first year, he reviewed the French edition of Beveridge's politically-oriented Full Employment in a Free Society (Piel 1946b), as well as Schumpeter's vast economic and sociologic analysis of 1942, the well-known Capitalism, Socialism and Democracy (Piel 1946a). Piel then made a joint review of Wilhelm Röpke's and Lévy Jacquemin's monographs, both dedicated to the issue of post-war international relations (Piel 1947). Finally, Piel examined Colin Clark's The Economics of 1960, an extrapolative essay in economic statistics (Piel 1948b). In spite of the diversity of those five books, Piel read them as preliminary contributions to the building of the societies of tomorrow.

By the end of 1948, Piel published La fortune américaine et son destin (1948a), the first title in Bataille's collection "l'usage des richesses" (Éditions de Minuit). The reading of Piel's book suggests two considerations. On the one hand, Piel's study was the result of a constant dialogue with Bataille, as is attested in particular by the book's penultimate section entitled "The economic function of the gift" (Piel 1948a, 208-11). Bataille wrote an enthusiastic review of Piel's book, published in Combat by the beginning of 1949 (O.C.XI, 432-3). On the other hand, Piel's knowledge of current economic debates was also valuable to Bataille's argument (as I will show in the next parts of the article). Yet, Piel's early study of the Marshall Plan was not Bataille's only inspiration, and Perroux played a decisive role in the completion of Bataille's work.

Perroux was one of the major French economists of the post-war period, probably the most influential if we consider both his theoretical contributions and his official 
responsibilities. Then professor of economics at the Law School of Paris, Perroux was directly involved in various research organisations: he was running the Institut de Sciences Économiques Appliquées (ISEA) he founded in 1944. This research centre was part of a network responsible for spreading "international innovations in the French context" (Fourcade 2009, 205), along the Ministry of Finance, the national statistical office (INSEE) or the Commissariat Général au Plan. This organ was in charge of indicative planification, and involved some of Perroux's closest associates, like Pierre Uri and Jean Fourastié.

Perroux's Le Plan Marshall ou L'Europe nécessaire au Monde (1948b) was among the first French studies to dissect the European Recovery Program. The book was built around four articles issued over a year, from June 1947 to June 1948 (hence some repetitions in the book's argument). Bataille (1948b) soon expressed his strong interest in a detailed bookreview for Critique. He also signed a shorter English version for the Times Literary Supplement (see Bataille 1949). Perroux (1948a) replied by letter to Bataille, out of curiosity for this surprising analysis and in view of answering some cutting remarks. The text was published in the November issue of Critique, followed by Bataille's brief rejoinder, where he concluded he was "glad to have given to one of the most original French economists the opportunity to clarify his thinking” (1948a, 1056).

We know from Perroux $(1971,42)$ that he met Bataille at some point in 1948, introduced by Piel. Even though no other meetings are mentioned by Perroux, he was probably in regular contact with Critique, at least for a short period of time. ${ }^{8}$ After the

\footnotetext{
${ }^{8}$ Perroux wrote two reviews on literary subjects for Critique, but did not contributed a single article related to economics. When the journal stop issuing a few months for financial reasons (from September 1949), Perroux was actively in search for new founds to sustain the publication. We don't know if Perroux lost contact with Critique because he was too busy, lost interest in the project or
} 
publication of The Accursed Share by the beginning of 1949, Perroux invited Bataille to give a lecture at the ISEA, which he eventually did on June $8^{\text {th }}$. Titled "The relations between the world and the sacred, and the growth of the forces of production," Bataille's text or notes - if there were - are still missing to this day. Similarly, we do not have any information on the audience's reactions. Some Critique contributors probably attended the lecture, as Bataille asked Perroux to invite Piel and Kojève, among others (377.PRX/181/27). In any case, Bataille's recollections of this lecture, added in the 1954 re-edition of La Part Maudite (O.C.VII, 480-1), concerned only Perroux's comments.

In the rest of this article, I will consider the studies by Perroux (1948b), Piel (1948a) and Bataille (O.C.VII) in close relation to one another, as contributing to a common debateas was at the time hinted by Jacques Vernant $(1949,580)$ in a joint book review of the three “convergent" titles. Nevertheless, we will see that, if Piel's and Bataille's studies were largely compatible and completed each other, Perroux's followed a rather independent theoretical agenda.

\section{A Revolutionary Plan? Theory and Policy Beyond National States}

In considering the first steps of the European Recovery Program, economists such as LévyJacquemin and Uri, or the philosopher Kojève (then statesman attached to the Ministry of Economic Affairs) were convinced that the Plan could "be described, without exaggeration, as

owing to a discord. Indeed in March 1950, Eric Weil (one of Critique's pillars) expressed genuine concerns about the quality of some contributions-Perroux being mentionned — in a letter to Bataille (in Patron 2014, 187). Bataille did not addressed directly Weil's doubts (at least in the correspondence), and confirmed his confidence in Perroux and Piel in a subsequent letter to the latter (in Surya 1997, 406). 
revolutionary" (Kojève 1949). ${ }^{9}$ But was the American aid leading western countries toward a change in the very nature of capitalism? For most commentators, it was too soon to say. According to Perroux, the Americans were setting up, by the "financing of a world-scale structural reform," the premises of a "new economy in its spirit and by its techniques" (1948b, 84, 123). He had no doubt that the Marshall Plan was ground-breaking: after all, it occasioned no less than "history's greatest experiment of credit and of managed economy" (Perroux 1948b, 162).

For his part, Bataille described the Marshall Plan as a "death or life issue for the American world" (1948b, 938). In other words: "either capitalism will organize itself and resolve its own contradictions, or its adversaries will destroy it with ease" (Bataille 1949). Yet Bataille refused to call the Plan revolutionary, as Perroux did in several parts of his book. The reason is twofold. First, how the Marshall Plan would practically work out was largely hypothetical. For the moment it was only "theoretically a profound negation of capitalism" (1948b, 938, italics added). Second, Bataille was attached to the full sense of the word revolutionary, and the steady path opened by the Plan was all but implying sudden changes in the economic structure (as we will see later, the American aid was nonetheless dictated by a revolutionary force, namely bolshevism). In consequence, Perroux's technical analysis was not interested in "the insertion of the plan in the real political game" (Bataille 1948b, 932-33). Bataille (ibid.) argued that the Marshall Plan had neither "the technical meaning," nor yet the "far-reaching political significance" that his "apologist [Perroux] gave it."

\footnotetext{
${ }^{9}$ For an analysis of Kojève's Hegelian reception of the Marshall Plan (with several references to Bataille) as an alternative to Carl Schmitt's framework of international relations, see Stefanos Geroulanos (2011).
} 
In his response to Bataille, Perroux denied this harsh epithet he judged uncalled-for, while recognizing that the latter had "precisely understood and faithfully spoken [his] crucial aims" (1948a, 1052). Perroux's defence is quite noteworthy: he maintained the revolutionary character of the present situation, but insisted it was less due to the American Plan per se, than to a change of perspective on the "relation between nations" implied by it (1948a, 1053). In fact, Perroux's enthusiasm was not only linked to the promise of an international or European "community," a concept he worked on at length during the interwar years from a communitarian-corporatist perspective (Cohen 2018), but also to new analytical challenges raised by the current international situation in general, and by the upcoming American aid in particular. The "revolutionary" aspect was closely associated to the current evolution of economic science and its capacity to account for the most recent phenomena, as Perroux clearly stated in his reply to Bataille (1948a, 1953).

In his book Le Plan Marshall, Perroux was already in search of what he termed a little later "the intellectual tools of the science of the twentieth century" (1950a, 104). Being clearly dissatisfied with the limits of contemporary economics, he underlined in particular two defects he aimed at correcting. First, economic theory showed a "congenital awkwardness in integrating into its analyses the notion of the strong and the weak" (Perroux 1948b, 69). Second, economists shared a great disregard for building a definition of space other than in the common-Euclidian - acceptation. Those two topics will be at the centre of Perroux's work from the early fifties on (see Couzon 2003; Sandretto 2009; Chassagnon 2015). Admittedly, the Marshall Plan was not the only source of Perroux's theoretical renewal in the post-war period. ${ }^{10}$ But the fact that Perroux's two theories were closely related to one another

\footnotetext{
${ }^{10}$ Previous international settlements as Bretton-Woods were part of Perroux's fixation on domination games between states. Also, Perroux's contribution to the making of French national accounting in
} 
and actually took shape within the discussions of the American Aid, has failed to be noticed in the literature.

The building of a theory of economic power, domination and force would involve new microeconomic conceptions. According to Perroux those were already under way, thanks to various theories of market competition worked out since the thirties. It was more urgent to develop the macroeconomic side of power analysis. Perroux used the expression of "dominant economy" in his book (1948b, 41), a concept he had elaborated a few months earlier in an article entitled "Esquisse d'une Théorie de l'Économie dominante" (Perroux 1947a). ${ }^{11}$ Theoretical in essence, Perroux's analysis was chiefly built on the US example - the current "international dominant economy" — and had already the "Marshall negotiations" in view (1947a, 295). Perroux's study aimed at accounting for both the deleterious and beneficial effects of a dominant economy on foreign — dominated—economies. Its key features can be summarized as follows:

The struggle for the fixation of the trade framework, the premeditated shift of the global demand curve by credit, and the propaganda and influence on structures are the essence of an unequal and peaceful competition which grow between the US and their trading partners (Perroux 1947a, 281).

The coming of an American aid (and not of usual credit) did not invalidate Perroux's contention. Indeed as Piel indicated, giving could also involve a certain kind of international

those years (see Perroux 1947b, 1949) was certainly an important step in noticing the difficulty to account for economic activities from a purely national outlook.

${ }^{11}$ This article was published in the September-October issue of Économie Appliquée (the journal of the ISEA). For a revised and shorter English version of this "Outline of a theory of the dominant economy," see Perroux (1950b). 
domination: if not direct "sovereignty transfer" between countries, at least a strengthening of the US “international paternalism" (1948a, 218-19). Yet paternalism was not necessarily problematic for Perroux, as long as it worked for a pacified international trade. This idea of a competition — admittedly unequal though peaceful — between national states would also draw Bataille's attention; though he did not mean it as a competition among western states, but as a competition between the two blocs, as I will show later.

Perroux was convinced that in international relations, domination and power struggles were the rule. He made his case for a "scientifically neutral ground" (1947a, 269 [n²]) to get rid of what he termed the "emotional vocabulary" of the Marxist theory of imperialismreminding us that the Cold War was also a struggle between alternative ways of saying the world. Nonetheless, Perroux was eager to stress that domination was less due to the rise of socialist or planned elements in market economies, than to the "very existence of national states" (1947a, 284). Thus every opportunity to organize economic international relations via a macro-structure beyond the standpoint of purely national interest, as for instance the Marshall Plan, was most welcomed in Perroux' eyes.

This leads us to the second shortcoming of contemporary economics: the lack of consideration for abstract spaces. Contrary to Perroux's theory of economic power, that was partly set forth when he published his 1948-book, the first outline of his theory of economic and human spaces came into existence through it, in a section dedicated to the "diversity of human spaces" (Perroux 1948b, 19-28). Perroux was looking for a notion of space separated from the common account for geography in purely monetary terms (prices and costs). The economic spaces he had in mind referred to three types of network relations: the plan, the field of forces (centrifugal and centripetal), and the relation of homogeneity (homogenous aggregate) with other units (Perroux 1950a, 93-94). 
Through this classification, on which there is no need to insist here (see Couzon 2003), Perroux underlined the almost systematic lack of coincidence between these economic spaces on one hand, and the political (national) territory, on the other. For Perroux, this was not a mere theoretical consideration, since political choices followed from the way in which decision-makers would consider spaces. Perroux aimed at a theoretical outlook "transcending the nation and the national economy" (1950a, 104), committed to a model of European Union based on a weakening of its frontiers, both within Europe itself and between Europe and foreign nations.

\section{The Making of a General Perspective}

Perroux saw the Marshall Plan experience as the opening of new intellectual spaces for economic reasoning. Bataille couldn't agree more. For both of them, current economics was for "no help whatsoever" in grasping the American aid in all its implications (Perroux 1948b, 173; Bataille 1948b, 934). Such project coincided for both authors in openly embracing joint "preferences" for a "general" economic outlook, as opposed to an "isolated" one (Perroux 1948a, 1055; Bataille 1948a, 1056). This explains why, apart from criticisms underlined above, Bataille was generally appreciative of Perroux's analysis, and built on it rather than contesting it.

Both Perroux and Bataille were fascinated by the Marshall Plan because it consisted in what they agreed to call a "global-interest investment" (Perroux 1948b, 160; quoted by Bataille 1948b, 934). The main liberal financial place in the world—the US—was planning to control surplus distribution on an international scale, and to do so on the ground of a heterodox doctrine of investment. Perroux (1948b, 126, sqq.) defined "classical" investment as a (1) private, (2) costly and (3) individual decision that (4) must be governed by the same 
rules whether on the national or international market. ${ }^{12}$ In his opinion, the Marshall aid was opposing these four characteristics. Although the plan mobilized the resources of capitalism, Perroux saw it as a rejection of the usual modes of financing and of rewarding capitalist investment.

For Bataille, speaking of "world-interest" was already a tremendous change in contemporary economic perspective. It was in patent contradiction with the usualerroneous - way "of the capitalist economy to ignore the general ends" and to "consider the general ends in the image of isolated ones" (1948b, 934). According to him, the BrettonWoods settlements failed to achieve this change of perspective. However, the Marshall Plan could complete the passage from "the primacy of isolated interest to that of general interest," i.e. to that of "interest of regional agreements" (Bataille 1948b, 934). In consequence, national states would disregard protectionism to the benefit of concerted ends, disconnected from the capitalist interest of creditors. A global institution would be in charge of making such an ideal come true:

Mankind embodied in a manager, Administrator of the Economic Co-operation Administration, would share the investment according to the basic law, negation of the rule of profit. (Bataille 1948b, 935)

Bataille was tacitly endorsing an international form for the socialization of investment praised by John Maynard Keynes, and eventually close to what the latter had in mind in Bretton Woods, but could not realise (see McGoey 2017, 9-11). However, Bataille went a step further: according to him, "consciously or not, the plan couldn't target another goal" than the

\footnotetext{
${ }^{12}$ Perroux was relying on Keynes' view from the first chapter of the General Theory. Perroux is considered as a prominent introducer of Keynesian ideas in postwar French economics (Rosanvallon 1989; Arena 2000; Cohen 2006) .
} 
fulfilment of the "elementary formula of communism", that is "the firm and unarguable principle: from each according to his ability, to each according to his needs" (Bataille 1948b, 935). If there was an obvious element of provocation in Bataille's claim, he was nonetheless convinced that the Marshall Plan had a better chance to achieve the ultimate communist ambition, than an actual soviet type of organisation.

For Bataille, the success of the Marshall Plan depended on its ability to renounce the usual law of profit, for that of the gift: that is, pure donations of products of human labour without paying any interest. In Perroux's more abstract words, the Marshall Plan's achievement was linked to "the degree to which industrial sovereignty, as well as national sovereignty, will be able to renounce their selfish and anxious exclusivism" (Perroux 1948b, 101). American support to European countries did not start with the European Recovery Program, but it replaced earlier dispositions, such as wartime lend-lease and intermediary support of all kinds (see Hill 1992; Williams 2005, 550, sqq.). However, that the American aid was intended to be largely free, without interest or repayment, virtually struck every French commentator. Such a colossal amount of gift "must baffle anyone trying to understand the contemporary world" according to Perroux's associate Jean Fourastié (1948, 563; see also Uri 1948, 28). Indeed in the short run, the Marshall Plan would lead to a fall in the American standard of livings caused by inflation; and thus it would be "absurd to consider that Marshall's exports are vital to American prosperity" (Fourastié 1948, 570). Absurd from an isolated economic perspective, from Bataille's general economy viewpoint contributing this "condemned wealth" $(1948 b, 938)$ was vital to the good health of the US economy, and beyond to that of the western world.

Bataille's theoretical view on economic issues was based upon the vision of a biological scheme ruling all living organisms, whether cells, plants or animals. The crucial characteristic for "living matter in general" would not be that of insatiable needs (the isolated 
viewpoint), but that of an energy "always in excess" (O.C.VII, 30-1). In a word, wealth and luxury—and not necessity—were the sources of the fundamental problems mankind was facing, and would be increasingly called to deal with.

Bataille's claim was not easy to argue for, especially in the early post-war period. One can only imagine the puzzled reactions of his contemporaries when, surrounded by European ashes and a population deprived of basic goods, Bataille insisted in a note published in July 1946:

Still today, it is generally accepted that the world is poor and that we have to work. The world, however, is sick with wealth. An opposite feeling is due to the inequality of conditions, which make us judging as missing to Pierre what is actually superfluous to Paul. Moreover, current shortages are the consequence of an abundance of energy. (Bataille O.C.VII, 15, italics added)

Wealth excess was, however, only one side of Bataille's "Copernican transformation" (O.C.VII, 33), the other being the structural limit to every kind of growth. For "there exists a point of saturation of the space open to life," and this space cannot grow linearly ant steadily but "faces limits" and "constantly stops." New starts—_successive leaps"—would have to wait for "changes in the conditions of life" (1948b, 937). Mankind had pushed very far the limits for growth possibilities through industry, which "uses energy for the development of the forces of production” (Bataille 1948b, 937). Nonetheless at some point, industrial societies would also reach a technological limit where excessive wealth will have no other opportunities - further growth being temporarily ruled out - than being unproductively used, or consumed in pure loss. ${ }^{13}$

\footnotetext{
${ }^{13}$ For detailed discussions of Bataille's general economy, see Jean-Joseph Goux (1990), Asger Sørensen (2012) and Pawlett (2015, chap. 5).
} 
In this light, Bataille saw the Marshall Plan as coherent to his general perspective insofar as it was "a renunciation of the growth of [US] productive forces" to the benefice of unproductive expenditure $(1948 \mathrm{~b}, 937) .{ }^{14}$ The American gift would not be a productive investment but a sacrifice: excessive wealth being destroyed in the sense that it was removed from the cycle of future production and accumulation. For Bataille, the essential question could be perceived as one of temporality, the Plan was an investment in present life, in final consumption:

In no way, in the Marshall Plan, the increase of the productive forces is deliberately preferred to the consumption of the products. [...] In a sense, it is a question of investing, but this investment has for its end-without waiting - the unproductive consumption, the relatively high standard of living of the workers, their relatively lower working time. (Bataille O.C.VII, 498-99)

The Marshall Plan was delaying growth by investing in other countries' capital funds. As soon as American capital goods "are shipped to Europe, these goods move from the productive chapter $(. .$.$) to the unproductive one, to the extent that they make European$ economies avoiding their own capitalization" (Bataille O.C.VII, 498-9, italics added). The last part of the sentence is crucial. As a matter of fact, Bataille did not disregard the further economic (productive) consequences of the American sacrifice. The Plan, he wrote, "anticipates an ultimate utilization for growth" but only to the extent that this opportunity is "carried over to an area where destruction — and technological backwardness — has left the field open" (1948b, 937).

Bataille's claim of the impossibility to accumulate productive forces limitlessly was a subject of contention with Perroux, raised on the occasion of Bataille's conference at the

\footnotetext{
${ }^{14}$ The notion of "expenditure" is a transversal issue of Bataille's works that goes well beyond purely economic aspects (see Kendall 2016).
} 
ISEA on June 1949. If Bataille cited Perroux arguing that his work touched upon a fundamental issue of economics, he also recalled that Perroux's insistence on the growth limitation hypothesis remained unproven. Bataille conceded that this hypothesis couldn't be verified in a scientific manner, but he reaffirmed his conclusion on the "disastrous effect caused by an increase of productive forces since the excess energy was not, either employed in this increase, or deliberately destroyed (consumed)" (O.C.VII, 480). To conclude on the required loss without profit of wealth excesses, Bataille's hypothesis did not need to be expressed in its strongest form denied by Perroux — that of a system that "can no longer grow"-but in a weaker form that Bataille suggested himself: when a system "cannot completely absorb [wealth] in its growth" (O.C.VII, 29). It's a safe bet to assume that Bataille saw the US economy as belonging to the second category (weak hypothesis) rather than to the first one (strong one).

In this case then, another hypothesis was left implicit by Bataille: that of the US economy having reach a point of saturation regarding domestic growth opportunities. In his 1946 article quoted above, Bataille (O.C.VII, 15) conceded that even "today, accumulation is perhaps far from its limits," even if unemployment worked as a compelling signal of current difficulties to dilapidate wealth excess. In his 1948 book review of Perroux, Bataille confirmed the quasi impossibility to accurately detect the point of saturation, being rather elusive on the question:

By and large, there exists in the world an excess share of resources that cannot contribute to a growth for which the "space" (better, the possibility) is lacking. Neither the share that it is necessary to sacrifice, not the moment of sacrifice, are ever given exactly. (Bataille 1948b, 938)

How can we explain Bataille's conviction that now was the right time for such a sacrifice? To a large extent, the very existence of the Marshall Plan came as an ex post validation of his intuition. In what follows, I will suggest that Bataille's hypothesis found further confirmation 
in Piel's work, and through him in the analysis of foreign economists.

In October 1947, Bataille outlined the aims and purposes of his new collection "l'usage des richesses" in a letter to Jérôme Lindon, editor at the Éditions de Minuit. In this brief text, coming a few months after Marshall's announcement, Bataille explained he intended first to "pursue an analysis already initiated by modern economics" (in Surya 1997, 379). Keynes is probably the leading economist Bataille had in mind-in support to what McGoey $(2017,3)$ called Bataille's “uneasy alliance”-, but we cannot rule out the possibility that he embraced a broadest acceptance of modern economics, which included debates among British and American (or New Dealers) Keynesians imported in France.

\section{Paradigms of Economic Maturity: Secular Stagnation vs. Condemned Wealth}

As Fourastié $(1948,562)$ noticed, analysing the mechanisms lying behind the Marshall Plan amounted to raising "one of the most important and exciting problems of contemporary economics: that of the almost indefinite development of the productive faculty of the great industrial nations.” Both Bataille and Fourastié were referring to contemporary economics as captured by a couple of expressions: the discussion on economic maturity, and within it the secular stagnation thesis.

I am not suggesting that Bataille had clearly in mind the most minute details of this academic debate. Yet there are at least three reasons for contextualising his reflexions within the discussion on economic maturity. First, this discussion touched upon theoretical issues significantly related to Bataille's claims discussed above, i.e. the limitations of economic growth. Second, it was explicitly examined in the work of French economists upon which Bataille built his reflexion, such as Perroux (rather unsympathetic to it, as explained above) and Piel (supportive of it, as I will show). Third, and from a broader perspective, this debate provided a vivid illustration of Bataille's dissatisfaction with the policy prescriptions of economists. 
The secular stagnation thesis was developed in the US in the late 1930s, but came to be widely debated in the aftermath of the war. Its main exponent was Alvin Hansen, an Harvard economist who had been much impressed by Keynes' General Theory (1936). Hansen claimed that the structural weakness of demand (caused by a declining population growth), if not compensated by a rise in technical progress, would lead to a fall in the overall amount of private investment, and consequently in the growth rate of economic activity (Backhouse et Boianovsky 2016, 950). In other words, the lack of new investment opportunities, set against an over-abundant level of savings, was the source of a "structural deflationary pression" (Dockès 2015, 975). Proper state intervention alone (in particular perennial public investment) could keep mature economies from a state of chronic unemployment. By the end of the war, the empirical side of the thesis, i.e. its application to the US economy, was refuted by the statistician George Terborgh (1945), calling for further reactions from Hansen's camp (see Dockès 2015, 977-79).

Piel was interested in the secular stagnation thesis to the extent that it could help to analyse the Marshall aid. In La fortune américaine et son destin (1948a), Piel referred explicitly to Hansen's Economic Policy and Full Employment (1947), as well as to an article by Benjamin Higgins (1946), Hansen's pupil. Piel gave the following explanation of stagnation:

The essential symptom of "maturity" is thus the accumulation of over-savings which, when not used, leads to a fundamental tendency to decrease in production, employment and income. Such consequences have been masked, and temporarily counteracted, by the last great wars [...]. The accumulation of purposeless reserves could, if not spent in some way, cripple the social organism. (Piel 1948a, 135-36)

Piel and Bataille shared the stagnationists' assessment of the economic situation. However, 
they could only see the solutions set forth by Hansen and his followers as unsatisfactory. ${ }^{15}$ Moreover, stagnationists did not endorse a theoretical justification for wealth destructionwhat Piel termed the "fire's share" (1948a, 211) and Bataille "condemned wealth" (1948b, 938) — but rather tried to avoid it.

In the framework of the Marshall Plan, Piel stressed that clearing the surplus through conventional interest loans was only viable in the short run, given the level of indebtedness of European countries, and the overall level of US production and exports of both manufactured and agricultural goods (Piel 1950). In the long run, "gift becomes the best and the only form of external credit" to the extent that "there is no other way out than the gift to the 'growth will' that has irresistibly animated the American community from the beginning" (1948a, 207, 223). In the same vein, for Bataille the crucial economic concern of the "old industrial nations," or mature economy, was less that of "outlets (already to a large extent questions of outlets have no possible answer)," than that "of consumption without profit compensation" (O.C.VII, 157). However, the idea of a necessary destruction of wealth—in particular regarding capital goods - following the ups and downs of the economic cycle, was far from being discounted by economists.

Paradoxically, Piel derived further arguments from a book that drew conclusions opposed to the secular stagnation thesis: The Economics of 1960 published during the war by the British/Australian economist Colin Clark (1942). Piel knew well the book he had reviewed for Critique (Piel 1948b), but there is strong evidence that Bataille was also aware of the content of Clark's monograph. In a letter dated March $25^{\text {th }}$, 1948, Bataille solicited Piel for an

\footnotetext{
${ }^{15}$ Keynsian-like economic policy would include lower the interest rate, reducing inequalities by wealth redistribution to increase propensity to consume, or to improve the role of the State as bank of investment.
} 
article to write together that "should start from Clark" (no record of this work has been found). Bataille was interested in building a more empirical argument "to numerically grasp," in the American context, the "principle of production to destroy" (Bataille to Piel in Surya $1997,387) .{ }^{16}$

In his book review, Piel denied Clark's too optimistic forecast on the US economy for the 1945-1960 period (precisely the statistical evidence Clark opposed to the secular stagnation thesis). However, Piel stood by what he perceived as the crucial "discovery" of Clark's study, rephrased in Bataillian vocabulary: the "fundamental necessity for periodical losses of energy, phases of disinvestment and of destructions being the only condition for further economic activity" (Piel 1948b, 465). In other words, the recurrence of overproduction crisis would be a necessary evil of capitalism. ${ }^{17}$ From this perspective, Clark's analysis worked as a further consolidation of Piel's and Bataille's argument. Bataille aimed at a comprehensive theory of excess, but the centrality of the economic aspect led him to engage in a discussion with contemporary economics, seconded by Piel's knowledge.

Few persons would be prepared to contradict Bataille when he claimed of not considering "the facts the way qualified economists do" (O.C.VII, 19). His confidence in

\footnotetext{
${ }^{16}$ By December 1950, a translation of Clark's book in Bataille's collection "l'usage des richesses" was under serious discussion (Bataile to Piel in Surya 1997, 429), but nothing was to come of it. It should be stressed that none of the announced titles (like a study by Lévy-Strauss or Bataille's second volume of The Accursed Share) were to issue, and the collection stopped after Piel's and Bataille's monographs. The collection ceased, and its budget was allocated to sustain Critique's publication after its financial difficulties (O.C.XI, 582-3).

${ }^{17}$ Clark's thesis was in fact less opposed than alternative to that of secular stagnation, in line with the tradition of long-run (Kondratiev) cycles of economic activity, and parallel to Schumpeter's waves of innovation (see Backhouse et Boianovsky 2016, 957).
} 
having cracked the "reasons that account for the mystery of Keynes's bottles" is, however, more surprising (O.C.VII, 22). Bataille's statement was not followed by any explanation whatsoever. Bataille probably assumed he had given the fundamental reasons explaining how a wholly unproductive expenditure, from an "isolated" perspective, could result in a productive outcome for the entire community. After all, Bataille was building "the first outlines of an economic interpretation of the general interest" according to Perroux (1948a, 1055). There is however a residual difficulty: to what extent was Bataille familiar with Keynes's writings?

As with other foreign economists, it seems likely that Bataille acquired a second-hand knowledge of Keynes through some of Critiques' contributors, in particular through Piel. ${ }^{18}$ In his review of Beveridge, Piel (1946b, 147-51) started by elaborating at length on Keynes, with a long quotation of his bottles metaphor. Piel set forth two claims. The first one was that even "sumptuous" spending, like in "the building of pyramids," was more helpful than doing nothing in order to "regulate the economic life and suppress unemployment" (Piel 1946b, 151). Second, the modern state remained the only actor capable of spending a tremendous amount of wealth regardless of its usefulness in purely micro- and short-run economic terms, as the experience of the World Wars taught us.

While Bataille's main concern in every facets of his work was achieving man's "selfconsciousness," the notion of general economy is specific in being perhaps his only theoretical contribution to "imply intervention in public affairs" (O.C.VII, 47). Like Piel, he was convinced of the vital necessity of "a continuous and deliberate regime of the energy flow" (Piel 1948b, 465), but not in the way economists were planning it. In Bataille's eyes,

\footnotetext{
${ }^{18}$ In a later recollection, Piel $(1995,98)$ elusively suggested that Bataille "had a 'rediscovery' of Keynes' books following the Second World War" (quoted by McGoey 2017, 20).
} 
there was nothing more dangerous than considering the US economy as a sustainable system, that could be managed in a "balanced and rational" way (O.C.VII, 161). In the last sentences of a chapter title "The meaning of General Economy," Bataille even warned the professional advocates of economic policies that they were far from being equal to the present circumstances:

An immense industrial network cannot be managed in the same way that one changes a tire... Woe to those who, to the very end, insist on regulating the movement that exceeds them with the narrow mind of the mechanic who changes a tire. (Bataille O.C.VII, 33)

It is tempting to read those lines as if they were addressed to Hansen's or Beveridge's “recipes"-Piel's word from the title of his book review (1946b) — or even to (a reductive image of) Keynes'. Indeed a few lines above the text quoted, Bataille implicitly pointed out that Keynes' national policies seemed no longer relevant to the present situation: "leaving aside pure and simple dissipation, analogous to the construction of the Pyramids, the possibility of pursuing growth is itself subordinated to giving" (O.C.VII, 33). What Bataille had in mind was something completely different from curing unemployment. For if the "active" (or deliberate) way of destroying wealth was not endorsed by the Americans through gifts, the only remaining "passive" solution would be that of the tragic outcome of war.

\section{Conclusion-Intellectual and Economist}

The post-war period is marked by frontier battles, on both actual and intellectual spaces. Economic science, in particular, experienced deep changes in the US, following a trend of autonomization and specialisation associated to the rise of new models of rationality within the Cold War context (Amadae 2003; Erickson et al. 2013) and to the building of a consistent neoclassical paradigm (Rutherford et Morgan 1998; Fourcade 2009, chap. 2; Düppe et Weintraub 2014). 
The French context is altogether different, and its process of normalization followed a rather long path. Post-war French economists were still keen on "the ideal of a unified social science," an idiosyncrasy according to Marion Fourcade (2009, 231-33). Hence in France, it was customarily practise for economists to address societal disputes as intellectuals, and conversely for intellectuals to take a stand on economic issues. Insofar as economists would raise crucial concerns about the foundations, the structure and the future prospects of social life, they would not fail to spark discussion across disciplinary fields. ${ }^{19}$ The Perroux-Bataille debate studied here provided an intricate combination of theoretical analysis and political considerations focused upon an unprecedent international event: the European Recovery Program.

From the moment the Marshall Plan was announced, it began to betray its initial objectives, burdened as it was by national and international political agendas. Yet, Perroux and Bataille agreed on its wide significance both for post-war capitalism and for economic theory. To regard this as naivety on the part of the authors would be a hasty judgment. Quickly disillusioned, Bataille noted in his 1954-reworked version of The Accursed Share that the US "repugnance" for an economic model of gift without profit "was the reason for the failure of an appealing plan" (Bataille O.C.VII, 481). ${ }^{20}$ Twenty years later, Perroux rather associated his and Bataille's judgement with inner circumstances: "Each of us spoke to the other of his own anxiety, of his own refusal and of his own heaven" $(1971,42)$. In this paper,

\footnotetext{
${ }^{19}$ At the very end of the $19^{\text {th }}$ century, Charles Péguy’s comment on Léon Walras' Éléments - as well as the correspondance associated to it—is a particualy telling exemple of the kind (see Bee 2011).

${ }^{20}$ As Piel $(1967,18)$ highlighted years after Bataille's death (in 1962), the latter became increasingly concerned with the circumstantial aspect of his analysis of the industrial development linked with the Marshall Plan, and wanted to re-write the book. A project he could not found time to fulfil.
} 
I argued that both Perroux and Bataille were contributing a unique and sophisticated economic reasoning across the narrow boundaries of scientific disciplines. It was precisely this ambition that lead them to a rather enthusiastic reception of the American aid: they were too anxious to stress the theoretical implications of the Marshall Plan for waiting its real practical consequences.

In Bataille's and Perroux's effort to assume simultaneously the role of the economist and of the intellectual, the former undeniably took the longer step. Indeed, Bataille was not well-versed in modern economics, yet it did not stop him from pursuing a radical project—a critique - from outside the canons of economic science. Jean Piel gave Bataille the opportunity to get in touch with some central economic debates of that time, notably by introducing him to that on economic maturity. If Bataille's madness could not found heirs within standard economic or political discourse, his legacy lived through the French Theory associated to the works of Michel Foucault, Jacques Derrida and Jean Baudrillard (Mansfield 2010; Pawlett 2018).

Perroux, on the other hand, followed a non-orthodox — if not heterodox — path within the scientific economic contribution that earned him the Chair of "Analyses of Economic and Social Facts" at the College de France from 1955 to 1974 . He is today considered as one of the main initiators of development economics (Weiller 1989; Hugon 2003; Maréchal 2003; Guillen 2010). While Perroux's collaboration to Critique proved short-lived, he remained keen to discussions across disciplinary fields all about his whole career. One of the latest illustrations of this attitude was Perroux's discussion with the German philosopher Herbert Marcuse, documented by an exchange of letter (see Marcuse et Perroux 1969).

To be sure, neither Bataille nor Perroux were "in the same kingdom" (Perroux 1971, 42) as everyone else. Yet their dialogue embodied a borderline case of particular interest: that 
of a less self-centred and more interdisciplinary-sensitive form of economic reasoning than we have become accustomed to.

\section{References}

Archival sources_-Fonds François Perroux [PRX], Institut de la Mémoire et de l’Édition Contemporaine (IMEC), Caen, France.

Amadae, S. M. 2003. Rationalizing Capitalist Democracy: The Cold War Origins of Rational Choice Liberalism. Chicago: University of Chicago Press.

Arena, Richard. 2000. «Les économistes français en 1950 ». Revue économique 51 (5): 9691007.

Backhouse, Roger E., et Mauro Boianovsky. 2016. « Secular stagnation: The history of a macroeconomic heresy ». The European Journal of the History of Economic Thought 23 (6): 946-70.

Bataille, Georges. 1948a. « Réponse (discussion sur l'aide américaine) ». Critique 4 (31): 1056.

—. 1948b. «Vers la fin de la guerre? » Critique 4 (29): 931-38.

_. 1949. « The Marshall Plan ». The Times Literary Supplement, $\mathrm{n}^{\circ}$ 2450: 35.

— O.C.I. Euvres Complètes: I. Premiers Écrits, 1922-40. Edited by Denis Hollier with a preface by Michel Foucault. Paris : Gallimard, 1970.

- O.C.VII. Euvres Complètes: VII. Paris : Gallimard, 1976.

_. O.C.XI. Euvres Complètes: XI. Paris : Gallimard, 1988.

_. O.C.XII. Euvres Complètes: XII. Paris : Gallimard, 1988.

-1991. The Accursed Share. Volume 1, Consumption: an essay on general economy. Traduit par Robert Hurley. New York: Zone Books.

Bee, Michele. 2011. «Les correspondances entre économie et philosophie dans les pensées de Léon Walras et de Charles Péguy ». In Léon Walras et l'équilibre économique général : recherches récentes, édité par Roberto Baranzini, André Legris, et Ludovic Ragni, 79-98. Paris: Economica.

Boltanski, Luc. 1981. « America, America... [Le Plan Marshall et l'importation du “management"]». Actes de la Recherche en Sciences Sociales 38 (1): 19-41. 
Brisset, Nicolas, et Raphaël Fèvre. 2018. « François Perroux, entre mystique et politique ». 04. University of Nice Sophia Antipolis: GREDEG, CNRS. https://ideas.repec.org/p/gre/wpaper/2018-04.html.

Caldari, Katia. 2018. « Alfred Marshall and François Perroux: the neglected liaison ». The European Journal of the History of Economic Thought 0 (0): 1-41. https://doi.org/10.1080/09672567.2017.1421678.

Chassagnon, Virgile. 2015. « Economic Power and the Institutions of Capitalism: Reappraising the Legacy of François Perroux ». Journal of Economic Issues 49 (1): 157-77.

Clark, Colin. 1942. The Economics of 1960. London: MacMillan.

Cohen, Antonin. 2006. « Du corporatisme au keynésianisme. Continuités pratiques et ruptures symboliques dans le sillage de François Perroux ». Revue française de science politique 56 (4): 555-92.

— 2018. « Why Call It a 'European Community'? Ideological Continuities and Institutional Design of Nascent European Organisations ». Contemporary European History 27 (2): 326-44.

Couzon, Isabelle. 2003. « «Les espaces économiques» de François Perroux (1950) ». Revue d'Histoire des Sciences Humaines, $\mathrm{n}^{\circ}$ 9: 81-102.

Dandurand, Guy. 1998. «"La Part maudite”, de Georges Bataille. Pour une lecture du paradoxe ». Littérature, $\mathrm{n}^{\circ}$ 111: 3-9.

De Long, Bradford J., et Barry Eichengreen. 1993. « The Marshall Plan: History’s Most Successful Structural Adjustment Program ». In Postwar economic reconstruction and lessons for the East today: conference organized by the Centre for Economic Policy Performance of the London School of Economics, édité par Rudiger Dornbusch, Wilhelm Nolling, et Richard Layard, 189-230. Cambridge ; London: MIT Press.

De March, François. 2015. « La Part maudite. Un "Non Savoir” économique? » In « La Part maudite » de Georges Bataille: la dépense et l'excès, édité par Christian Limousin et Jacques Poirier, 119-34. Paris: Classiques Garnier.

Dockès, Pierre. 2015. «Les débats sur la stagnation séculaire dans les années 1937-1950, The debate on secular stagnation in the years 1937-1950 ». Revue économique 66 (5): 967-92.

Dodd, Nigel. 2016. The Social Life of Money. Princeton: Princeton University Press.

Domarchi, Jean. 1948. « Discussion sur le Plan Marshall. Du “plein emploi” au Plan Marshall ». Les Temps Modernes 29: 1345-71. 
Drake, David. 2002. Intellectuals and politics in Post-War France. Basingstoke: Palgrave Macmillan.

Dufourt, Daniel. 2009. «L'avènement d'une épistémologie politique dans l'œuvre de François Perroux ». Économie et Société - série M 33 (3): 419-47.

Dulphy, Anne. 2005. « La gauche et la guerre froide». In Histoire des gauches en France, 416-34. Paris: La Découverte.

Düppe, Till, et E. Roy Weintraub. 2014. « Siting the new economic science: The Cowles Commission's activity analysis conference of June 1949 ». Science in Context 27 (03): $453-483$.

Erickson, Paul, Judy L. Klein, Lorraine Daston, Rebecca Lemov, Thomas Sturm, et Michael D. Gordin. 2013. How Reason Almost Lost Its Mind - The Strange Career of Cold War Rationality. Reprint. University of Chicago Press.

Falasca-Zamponi, Simonetta. 2011. Rethinking the Political: The Sacred, Aesthetic Politics, and the Collège de Sociologie. McGill-Queen's Press - MQUP.

Fourastié, Jean. 1948. « Les États-Unis pourront-ils tenir les engagements prévus par le plan Marshall? » Esprit 144 (4): 562-74.

Fourcade, Marion. 2009. Economists and Societies - Discipline and Profession in the United States, Britain, and France, 1890s to 1990s. Princeton: Princeton University Press.

Fraisse, Paul. 1948. « Les Français face à leurs responsabilités ». Esprit 144 (4): 623-31.

Geroulanos, Stefanos. 2011. «Heterogeneities, slave-princes, and Marshall plans: Schmitt's reception in Hegel's France ». Modern Intellectual History 8 (3): 531-560.

Goguel, François. 1948. « Le plan Marshall devant les partis français ». Esprit 144 (4): 619-22.

Goux, Jean-Joseph. 1990. « General Economics and Postmodern Capitalism ». Traduit par Kathryn Ascheim et Rhonda Garelick. Yale French Studies, nº 78: 206-24.

Guillen, Romo. 2010. « François Perroux: Pionnier oublié de l'économie du développement ». Économie appliquée LXIII (4): 73-101.

Hansen, Alvin Harvey. 1947. Economic Policy and Full Employment. New York: McGraw-Hill Book Company.

Higgins, Benjamin. 1946. « The Doctrine of Economic Maturity ». The American Economic Review 36 (1): 133-41.

Hill, John S. 1992. « American Efforts to Aid French Reconstruction between Lend-Lease and the Marshall Plan ». The Journal of Modern History 64 (3): 500-524. 
Holm, Michael. 2016. The Marshall Plan: A New Deal For Europe. New York: Routledge.

Hugon, Philippe. 2003. « Le concept d'acteurs du développement chez les pionniers du développement : Albert Otto Hirschman et François Perroux ». Mondes en développement 124 (4): 9-31.

Kendall, Stuart. 2016. « Expenditure ». In Georges Bataille: Key Concepts, édité par Mark Hewson et Marcus Coelen, 75-87. London \& New York: Routledge.

Keynes, John Maynard. 1936. The General Theory [The Collected Writings of John Maynard Keynes-VII]. London; Basingstoke: Macmillan, 1973.

Kojève, Alexandre. 1949. « Les origines, le but, la situation actuelle et les perspectives d'avenir de l’Organisation Européenne de Coopération Économique », 24 septembre 1949, FranceIllustration édition.

Kroen, Sheryl. 2006. « Renegotiating the social contract in post-war Europe: the American Marshall Plan and consumer democracy ». In Consuming cultures, global perspectives: historical trajectories, transnational exchanges, édité par John Brewer et Frank Trentmann, 251-277. Oxford, New York: Berg.

Lynch, Frances M. B. 1984. « Resolving the Paradox of the Monnet Plan: National and International Planning in French Reconstruction ». The Economic History Review 37 (2): $229-43$.

Mansfield, Nick. 2010. The God Who Deconstructs Himself: Sovereignty and Subjectivity Between Freud, Bataille, and Derrida. New York: Fordham Univ Press.

Marcel, Jean-Christophe. 2003. « Bataille and Mauss:a dialogue of the deaf? » Economy and Society 32 (1): 141-52.

Marcuse, Herbert, et François Perroux. 1969. François Perroux interroge Herbert Marcuse ...qui répond. Paris: Aubier-Montaigne.

Maréchal, Jean-Paul. 2003. «L'héritage négligé de François Perroux ». L'Économie politique 4 (20): 47-63.

McGoey, Linsey. 2017. « Bataille and the Sociology of Abundance: Reassessing Gifts, Debt and Economic Excess ». Theory, Culture \& Society, juillet, 0263276416637905. https://doi.org/10.1177/0263276416637905.

Patron, Sylvie. 2000. Critique, 1946-1996: une encyclopédie de l'esprit moderne. Paris: Éditions de l'IMEC. 
—_. éd. 2014. A en-tête de « Critique » : Correspondance entre Georges Bataille et Eric Weil. Paris: Nouvelles Editions Lignes.

Pawlett, William. 2015. Georges Bataille: the sacred and society. London: Routledge.

- 2018. « The Sacred, Heterology and Transparency: Between Bataille and Baudrillard». Theory, Culture \& Society, avril. https://doi.org/10.1177/0263276418769729.

Perroux, François. 1947a. «Ésquisse d'une théorie de l'économie dominante ». Économie appliquée. Archives de l'ISEA, 243-300.

—_. éd. 1947b. Le Revenu national : son calcul et sa signification. Paris: Presses Universitaires de France.

—. 1948a. « Discussion sur l’aide américaine ». Critique 4 (31): 1052-55.

_. 1948b. Le Plan Marshall ou l'Europe nécessaire au Monde. Paris: Librairie de Médicis.

-1949. Les Comptes de la Nation. Paris: Presses Universitaires de France.

_. 1950a. « Economic Space: Theory and Applications ». The Quarterly Journal of Economics 64 (1): 89-104.

_. 1950b. « The Domination Effect and Modern Economic Theory ». Social Research 17 (2): 188-206.

- 1971. « La Part maudite et le silence ». L'Arc, nº 44: 42-47.

Piel, Jean. 1946a. « Du capitalisme au socialisme selon Schumpeter ». Critique 1 (3-4): 317-24.

—. 1946b. « Les recettes économiques de Beveridge ». Critique 1 (2): 148-55.

—. 1947. «Vers une économie mondiale fondée sur le don ? » Critique 2 (17): 343-52.

_. 1948a. La fortune américaine et son destin. Paris: Éditions de Minuit.

—. 1948b. « Les prophéties de Colin Clark à l'épreuve des faits ». Critique 3 (24): 457-65.

. 1950. « La politique américaine de soutien des prix agricoles ». Revue économique 1 (4): 480-93.

—. 1967. «Introduction. Bataille et le monde ». In La part maudite ; précédé de La notion de dépense, par Georges Bataille, nouvelle Ed., 9-18. Paris: Les Editions de Minuit.

- 1995. «Bataille and the World From "The Notion of Expenditure" to the Accursed Share ». In On Bataille: critical essays, édité par Leslie Anne Boldt-Irons, 95-106. Albany: State University of New York Press.

Rabier, Jacques-René. 1948. «Plan Monnet et plan Marshall ». Esprit 144 (4): 575-97. 
Ramp, William. 2003. « Religion and the dualism of the social condition in Durkheim and Bataille ». Economy and Society 32 (1): 119-40.

Richman, Michèle. 1990. « Bataille Moralist?: Critique and the Postwar Writings ». Yale French Studies, $\mathrm{n}^{\circ} 78:$ 143-168.

- 2002. Sacred revolutions: Durkheim and the College de Sociologie. U of Minnesota Press.

Roberts, Geoffrey. 1994. « Moscow and the Marshall plan: Politics, ideology and the onset of the cold war, 1947 ». Europe-Asia Studies 46 (8): 1371-86.

Rosanvallon, Pierre. 1989. « The Development of Keynesianism in France ». In The Political Power of Economic Ideas: Keynesianism Across Nations, édité par Peter A. Hall, 171-94. Princeton: Princeton University Press.

Rutherford, Malcolm, et Mary S. Morgan, éd. 1998. «From Interwar Pluralism to Postwar Neoclassicism ». In . Vol. 30. History of Political Economy (Annual Supplement). Durham and London: Duke University Press.

Sabot, Philippe. 2014. « Bataille, entre Kojève et Queneau: le désir et l'histoire ». Le Portique. Revue de philosophie et de sciences humaines, $\mathrm{n}^{\circ}$ 29: 1-13.

Sandretto, R. 2009. « François Perroux: a precursor of the current analyses of power ». The Journal of World Economic Review 5 (1): 57-68.

Scot, Marie. 2016. «L'antiaméricanisme dans la vie intellectuelle française ». In La vie intellectuelle en France. De 1914 à nos jours, édité par Christophe Charle et Laurent Jeanpierre, traduit par Sophie Renaut, 2:381-86. Paris: Seuil.

Sørensen, Asger. 2012. « On a Universal Scale: Economy in Bataille’s General Economy ». Philosophy \& Social Criticism 38 (2): 169-97.

Soria, Georges. 1948. La France deviendra-t-elle une colonie américaine? Paris: Éditions du Pavillon.

Steil, Benn. 2018. The Marshall Plan: Dawn of the Cold War. Oxford: Oxford University Press. Stoek1, Allan. 1997. « Bataille, Gift Giving, and the Cold War ». In The logic of the gift: toward an ethic of generosity, édité par Alan D. Schrift, 245-55. New York: Routledge.

Surya, Michel, éd. 1997. George Bataille. Choix de lettres : 1917-1962. Paris: Gallimard.

—. 2002. Georges Bataille: An Intellectual Biography. New York: Verso.

Terborgh, George. 1945. The bogey of economic maturity. Chicago: Machinery and Allied Products Institute. 
Thérien, Jean-Philippe. 2002. « Debating foreign aid: Right versus left ». Third World Quarterly 23 (3): 449-66.

Uri, Pierre. 1948. « Discussion sur le Plan Marshall. Une stratégie économique ». Les Temps Modernes 34: 12-41.

Véran, André. 1948. «Visages américains du plan Marshall ». Esprit 144 (4): 541-554.

Vernant, Jacques. 1949. Review of Une interprétation du Plan Marshall, par François Perroux, Jean Piel, et Georges Bataille. Politique étrangère 14 (6): 575-80.

Weiller, Jean. 1989. « François Perroux, un grand contestataire ». Revue française d'économie 4 (2): 27-41.

Williams, Andrew J. 2005. «'Reconstruction' before the Marshall Plan ». Review of International Studies 31 (3): 541-58.

Winock, Michel. 1996. " Esprit», des intellectuels dans la cité : 1930-1950. Nouv. éd. revue et augmentée. Paris: Seuil. 